\title{
Review: The Sanga-Shari Borderlands
}

Author(s): F. R. C.

Review by: F. R. C.

Source: The Geographical Journal, Vol. 34, No. 3 (Sep., 1909), pp. 330-331

Published by: geographicalj

Stable URL: http://www.jstor.org/stable/1777153

Accessed: 27-06-2016 03:05 UTC

Your use of the JSTOR archive indicates your acceptance of the Terms \& Conditions of Use, available at

http://about.jstor.org/terms

JSTOR is a not-for-profit service that helps scholars, researchers, and students discover, use, and build upon a wide range of content in a trusted digital archive. We use information technology and tools to increase productivity and facilitate new forms of scholarship. For more information about JSTOR, please contact support@jstor.org.

The Royal Geographical Society (with the Institute of British Geographers), Wiley are collaborating with JSTOR to digitize, preserve and extend access to The Geographical Journal 
of his route together with a few photographs of typical landscapes. That route took him from Lindi along the Lukuledi, and then, skirting the plateal, south to Newala, not far from the Rovuma; here he mounted the plateau and struck north, eventually hitting the Lukuledi not far from its mouth. The tribes with which the book deals are the Makonde, from whom the plateau takes its name, and the scattered groups of Wayao, Wanyassa, and Makua found in the plains to the west and south-west. Of these the first-named afford by far the greatest interest; less is known about them, and their culture has been less influenced by the coastal peoples. In particular the division into matriarchal exogamous groups, which has almost disappeared among the other tribes, is here found in full force. The great feature of the work is a very full description of the puberty ceremonies relating to both sexes in force among Wayao and Makonde, and Dr. Weule is to be congratulated on having secured a far more detailed description of these performances than usually falls to the lot of the student of more or less secret rites. Of particular interest are the remarkable masks employed by the Makonde on these occasions, many of them covering the upper part of the body as well as the head, and representing women; the use of stilts in ceremonial dances was also found here. The author also collected an unusual number of traps used for the capture of birds and mammals, small and large, besides other specimens represen branch of cultural activity. Of his general observations one of the most interesting is his remark that the use of the lip-plug, so prevalent throughout this area, is a very potent cause of decay in teeth, to which the Makonde seem liable in a degree unusual amongst a primitive people. At the end he pleads for an attempt to introduce a more hygienic manner of life amongst the native tribes, the want of which lies at the rcot of the sadly high percentage of infant mortality. The book is illustrated by sixty-three admirable plates, mostly in collotype, to which a special word of praise is due; and the extreme lowness of the price $(3 \mathrm{~m}$.$) at which it is$ issued bids one suppose that here again the German Government shows wisdom in subsidizing the publication of works which help to set administration on a scientific basis. Not the least valuable of the accompanying features of the volume are an excellent map in colours and an adequate index.

T. A. J.

\section{The Sanga-Shaki Bordertands.}

'La Decouverte des Grandes Sources du Centre de l'Afrique.' By Commandant Lenfant. 115 Illustrations and a Coloured Map. Paris: Hachette et Cie. 1909. $12 f r$.

In the introduction to this volume Commandant E. Lenfant states that when he was a lad the reading of the exploits of David Livingstone and II. M. Stanley fired in him the desire, like them, to penetrate into the unknown. That wish he has gratified, and to-day he occupies a place among the foremost of the followers of the great African explorers. In 1903 he demonstrated the water connection between the Benue and the Logone; the expedition of 1906-7, of which we have here the general account, was devoted to the investigation of the district containing the western sources of the Shari and the upper waters of the Sangha. 'The chief results obtained, including the discuvery that the Whame-Bahr Sara is the parent stream of the Shari, have already been noticed in the Journal. A technical treatise on the geographical work of the mission is to come from Captain Periquet, but a summary thereof appears in this book, which also contains general descriptions of the country traversed, studies of the peoples encountered, and the adventures of the mission. The region explored is divided into three zones: (1) the southern, or basin of the Sangha, a land of dense forest; (2) the central, a rocky plateau; (3) the northern, or plains of the Logone, a grass-covered open land with 
clayey soil (the bed of some forgotten lake). The exploration of the central zone, called the Massif de Yade, was the great achievement of the mission. In the belief of the author, this granitic mass, fairly level in the centre, but presenting abrupt sides with many peaks, is the hard core which has resisted the wearing away of the land which surrounds it. From it "as from an immense reservoir" rise "all the rivers which water Central Africa." The statement, which is an obvious exaggeration, is reflected in the title of the book, but from this hydrographic centre issue the headwaters of the Sangha, the Logone and the Shari, and of the Lom or Sanaga. Commander Lenfant shows clearly the effect of the nature of the country on the life and morals of the inhabitants. Thus in the dense forest zone of the Sangha, where no domestic animals thrive and few exist, the natives (Bayas, Yanghérés, etc.) are anthropophagus, and live largely on manioc; in the northern zone, where herbage is abundant, cannibalism is not practised, the inhabitants (M'Boums, Lakkas, Saras, etc.), possessing large herds of cattle, and raising plentiful crops of millet. Naturally, this latter group of peoples is superior to the first group both in physique and culture. The ethnologist will indeed find Commandant Lenfant's pages full of information and suggestion. He discusses the question of cannibalism with an interesting detachment and in the spirit of a social reformer. He holds this practise to be "the son of necessity rather than the result of fetishism." In short, anthropophagism is the palliative "des chasses infructueuses, du bétail absent et de ce que les indigènes appellent le 'mauvais goût dans la bouche." "The use of this expression by a tribe is, indeed, an almost absolute proof that it practises cannibalism, the "bad taste" being caused by the absence of sufficient salt in their food. An extremely interesting chapter is devoted to a description of $l a b i$, a term which indicates a special mental, moral, and physical training which many young men of many different tribes undergo. There is a special labi language, a sort of Esperanto, which thus becomes a general means of communication. Space does not permit even mention of other subjects dealt with in this really fascinating book. We can only add that the illustrations are many and good. The map, which is based on some 180 positions astronomically determined, shows clearly the river courses, but no heights are given. From the text it appears that the highest points are about 4000 feet above sea-level.

F. R. C.

The Canaries.

'Les Iles Canaries.' By L. Proust and J. Pitard. Illustrations and a Map. Pp. 320. Paris: Guilmoto. [No date; 1909.] Price $10 \mathrm{fr}$.

The two authors have succeeded in writing a pleasant descriptive work on the Canary islands, in which they have omitted no aspect that could be of interest to the visitor or casual traveller. The book is certainly far above the standard of an ordinary guide-book, and yet, despite its comprehensive nature, can scarcely make serious pretensions to geographical merit. The flora is the only aspect of the islands which receives anything like adequate scientific treatment. A description of the islands, their peoples and activities, occupies the greater number of the pages, and only a brief chapter is devoted to physical geography. The origin of the Canaries as being the remaining tops of the lost continent of Atlantis is advocated, and proofs are adduced from the botany of the islands in support of the theory. But to the authors' mind the indisputable proof is to be found in the absence.of Tertiary beds in the Canaries, because during all this epoch the islands were above the sea. The presence of limestome beds in the islands is certainly evidence of their past connection with a larger land-mass, possibly northern. Africa; but the authors have scarcely given convincing proofs of the existence of Atlantis. 